\title{
O APOLO DESMESURADO D'O NASCIMENTO DA TRAGÉDIA CONTRA OS INTÉRPRETES DE NIETZSCHE ${ }^{1}$
}

Marco Sabatini (Unifesp) ${ }^{2}$

marco_rsabatini@hotmail.com

Resumo: Grande parte das análises sobre $\mathrm{O}$ nascimento da tragédia rodeiam os impulsos apolíneos e dionisíacos que, em comunhão, teriam originado a tragédia grega. Quando se referem ao apolíneo, a explicação tradicional se concentra em algumas características como a beleza, a aparência, a ética e o sonho. No entanto, o primeiro livro de Nietzsche apresenta uma série de períodos relacionados a Apolo que destoa de sua posterior tradição interpretativa. Um dos mais evidentes é o período dórico que utilizo aqui a fim de demonstrar um Apolo desmesurado em $\mathrm{O}$ nascimento da tragédia contra sua habitual caracterização como um deus belo e ético.

Palavras-chave: Desmesura; Apolo; Filologia; Grécia Antiga.

\section{INTRODUÇÃO}

Em O nascimento da tragédia, Apolo e Dioniso são os pilares que sustentam as hipóteses estéticas e existências de Nietzsche sobre os gregos antigos. "A seus dois deuses da arte, Apolo e Dioniso, vincula-se a nossa cognição de que no mundo helênico existe uma enorme contraposição, quanto a origens e objetivos, entre a arte do figurador plástico, a apolínea, e a arte não figurada da música, a de Dioniso" (NIETZCHE, 2007b, p. 24). Isso não impede que ambos os

\footnotetext{
${ }^{1}$ Recebido: 29-07-2014/Aprovado: 01-08-2015/Publicado on-line: 31-08-2015.

${ }^{2}$ Marco Sabatini é Doutorando pela Universidade Federal de São Paulo, São Paulo, SP, Brasil.
} 
deuses caminhem juntos; ao contrário, Dioniso e Apolo precisam um do outro para atingir o máximo grau de afirmação da vida, como se se potencializassem e se efetivassem exatamente em seu oposto.

No entanto, a consideração de Nietzsche por tais divindades se torna desproporcional ao longo de sua vida. Em seus últimos escritos publicados, somente Dioniso predomina, enquanto Apolo parece não mais precisar de nenhum testemunho. Segundo Deleuze, Nietzsche percebe ao longo de sua obra que a verdadeira contraposição não se faz entre essas divindades. "Não é Apolo que se opõe ao trágico ou pelo qual o trágico morre, é Sócrates" (DELEUZE, 1976, p. 11). Já em O nascimento da tragédia, Sócrates e outros sábios gregos se apresentavam "como sintomas de declínio, como instrumentos da dissolução grega, como pseudogregos, antigregos" (NIETZSCHE, 2006a, p. 18). Para Deleuze, as ideias juvenis de Nietzsche culminaram inevitavelmente no ataque exaustivo a Sócrates. A filosofia socrática refletiria assim um corpo cansado, melancólico, doente, contrário à vida: "Sócrates queria morrer: - não Atenas, mas ele deu a si veneno, ele forçou Atenas ao veneno..." (NIETZSCHE, 2006a, p. 23). Por isso, em sua maturidade, não faria sentido dar primeiro lugar a DionisoApolo; seria necessário encontrar a verdadeira contraposição à afirmação da vida que se expressava na relação consumada daqueles dois deuses.

Em um primeiro momento, Sócrates resiste a DionisoApolo, mas ele não é a oposição plena, ainda segundo a interpretação deleuziana, pois também Sócrates fez música (NIETZCHE, 2007b, p. 88). Será preciso então "que o homem trágico, ao mesmo tempo em que descobre seu próprio elemento na afirmação pura, descubra seu inimigo 
mais profundo como aquele que conduz verdadeiramente, definitivamente, essencialmente, a tarefa de negação" (DELEUZE, 1976, p. 11). Dessa forma, Deleuze tenta demonstrar que Apolo cede o seu lugar a um elemento puramente afirmador, o dionisíaco, para combater o verdadeiro inimigo de ambos, um inimigo mais forte que Sócrates: o Crucificado.

Mas é difícil assumir inteiramente a exposição deleuziana em relação a Apolo. Em Nietzsche e a Filosofia, Deleuze faz uma mistura propositada das obras e ideias nietzschianas para fundamentar as suas interpretações. Se Apolo cede o seu lugar a Dioniso, então devemos nos perguntar quem é este Apolo?, quem é este Dioniso?, qual é o tempo? e qual é o lugar? que eles habitam no pensamento nietzschiano. Ou seja, assumir que Nietzsche possui a mesma consideração sobre o apolíneo em sua juventude e em sua maturidade pode conter seus perigos. No entanto, o propósito de Deleuze se concentra no dionisíaco nietzschiano tardio e não nas lógicas internas do apolíneo e suas complicações.

Quando, porém, temos em vista os textos de juventude, sobretudo $\mathrm{O}$ nascimento da tragédia, não podemos adotar uma atitude semelhante em que congela a concepção nietzschiana sobre Apolo. Ao contrário, devemos revirar ao máximo Apolo e o apolíneo, questioná-los, problematizá-los como se a hermenêutica foucaultiano nos impingisse um trabalho infinito (FOUCAULT, 1997, p. 26). Dessa forma, a tradição dos intérpretes nietzschianos sobre Apolo se torna problemática, porque ela não concebe Apolo em seus movimentos. Identifica-o com a aparência, a ilusão, a beleza, a ética; mas o petrifica nestas características, como se o Apolo nietzschiano fosse dotado de uma Naivität tão intensa que ultrapassasse patologicamente sua linha onírica. As 
exceções são, geralmente, céleres ao tentar demonstrar que também o Apolo nietzschiano possuiu suas terribilidades, feiuras, aéticas. Obviamente, aqueles olímpicos atributos apolíneos transpassam majoritariamente o pensamento de Nietzsche. No entanto, quero afirmar que elas se concentram em um momento específico de $\mathrm{O}$ nascimento a tragédia; para isso, nada melhor do que expor o exemplo adverso: um Apolo desmesurado.

\section{OS APOLOS DA GRÉCIA ANTIGA}

As histórias de Apolo e de seus cultos são riquíssimas. Com tantos nomes e variações de Apolo, parece significativo a revelação de personalidades e originalidades por meio de vinculações sintagmáticas.

Sabe-se que, entre vários povos, sacrifícios humanos rituais eram executados, dramatizando o sacrificante a morte da vítima, como se fosse a sua própria - isto é, como se o sacrificante se autoimolasse. Basta lembrarmos que, tanto o sacerdote asteca ao imolar uma vítima, como o tupinambá, que mata o prisioneiro inimigo, eram os únicos a não comer da carne do imolado. Curiosamente, tanto um como outro proferiam as mesmas palavras rituais: "não como da minha carne”. Fácil é, assim, perceber que o sacrificante toma para si também o nome de sua vítima, assim como Atena passa a chamar-se Palas Atena após vencer o gigante Palas. (CARVALHO, 2010a, p. 179-180)

Quando Homero (2004) se refere a "Zeus Crônida" (p. 329) ou o "prepotente, nascido de Cronos" (p. 118), tem-se algo como pressuposto. "Segundo Brelich, parece admissível que, em alguns casos, os oráculos tenham sido divindades mais antigas (Píton, Ptoio, Ismeno, Sarpédon) como donos e foram depois usurpados por Apolo" (CARVALHO, 2010a, p. 180). Assim, uma tradição cultural concentra-se nos nomes apolíneos. Junito Brandão diz 
que "o Apolo da Ilíada é um deus mais caseiro, um deus de santuário, uma divindade provinciana. Preso à sua cidade, comporta-se como um deus tipicamente asiático: é o deus de Tróia e lá permanece" (1987, p. 137). No entanto, segundo Otto, "a tradição moderna vê nele um deus vindo do Oriente; mas embora ele tenha pertencido antanho, sem dúvidas alguma, aos deuses da cultura pré-helênica, sua imagem não comporta nenhum traço oriental" (2006, p. 139).

Porém, no Canto I de Ilíada, Apolo "peste lançou destruidora no exército" (HOMERO, 2004, p. 58) de Agamémnon por este ter ultrajado seu sacerdote, Crises. Os versos 458-474 mostram o sacrifício feito a Apolo para amenizar a sua cólera. "Quando queimadas as coxas e as vísceras todas comidas,/ logo o restante retalham, espetos enfiam nas postas, / e cuidadosos as tostam, tirando-as, depois, dos espetos" (HOMERO, 2004, p. 71). O sacrifício era, geralmente, consagrado a um deus enfurecido por algum ato humano; para mitigar a sua cólera, ofereciam-lhe a vida. Assim, o sacrifício feito a Apolo no Canto I da Ilíada estaria disfarçado pela beleza das palavras homéricas. Nessa cena, Apolo é o deus colérico que sacia a sua vingança e se alegra através de um ritual cujas significações parecem mais antigas do que a própria beleza apolínea. Além disso, apaixonou-se por Cassandra e lhe presenteou com o dom da profecia; após um tempo, desentendeu-se com ela; sem poder retirar-lhe a dádiva, cuspiu em sua boca para que ninguém acreditasse em suas predições. Violentou a bela ateniense Creusa. Perseguiu a ninfa Castália até que ela se atirasse em uma fonte a fim de escapar dele. Desafiado a um duelo de flautas pelo sátiro Mársias, Apolo foi declarado vencedor pelas Musas e perdedor pelo rei Midas, juízes 
da disputa; após a sua vitória, o deus puniu o rei dando-lhe orelhas de burro e amarrou o seu rival a uma árvore, esfolando-o vivo (BRANDÃO, 1987, p. 89) .

Para Otto, no entanto, "a afirmação de que mesmo em Homero ele ainda aparece como um deus asiático e como um poder lúgubre e mortífero baseia-se em uma série de interpretações equívocas" (2006, p. 139), pois, enquanto Apolo demonstra alguns traços de crueldade, "na religião olímpica, ele se revelou de uma maneira nova, na medida em que todos os seus antigos predicados assumiram um sentido mais espiritual" (OTTO, 2006, p. 140). Nos mitos olímpicos, Apolo, flecheiro infalível, é lindo. Consciente de sua beleza, ele seduziu ninfas e musas em casos amorosos, por vezes, trágicos; relacionou-se com Cirene, Talia, Urânia, Calíope, Corônis, Marpessa, Cassandra, Manto (BRANDÃO, 1987, p. 87-88) .

De acordo com Torrano, "sob certos aspectos os pais não são anteriores aos filhos, mas são em muitos casos determinados e marcados por eles ou por 'pósteros', como se fossem todos 'contemporâneos"” (2001, p. 68). O Hino Homérico 4: a Hermes narra que Apolo se maravilhou ao ouvir o som da cítara de Hermes; indignado por ser o companheiro das Musas e não conhecer aquele tipo de música, pergunta a Hermes: "Que arte é essa? Que musa é essa de incontroláveis cuidados?/ Qual é o caminho?" (HOMERO, 2010b, p. 440), Apolo está rendido a si mesmo! - e Hermes, deus jovem e arteiro, sabe disso, respondendo-o:

Fazes-me perguntas hábeis, Arqueiro; mas não me oponho a que tenhas acesso a uma arte que é nossa! Hoje mesmo aprenderás! Tenciono ser propício para ti em desígnios e em palavras; e tu bem sabes tudo no coração! És, filho de Zeus, o primeiro a ter assento entre os imortais, cheio de força e poder; ama-te o prudente Zeus com toda justiça, e concedeu-te dons esplêndidos! 
e dizem que aprendeste de Zeus as honras dos oráculos e profecias, Arqueiro - de Zeus vêm todos os vaticínios! Que és pródigo dessa arte já sei, por vivência própria.

Só de ti, porém, depende aprender o que anseias! [itálicos meus] (HOMERO, 2010b, p. 442)

Apesar de Hermes ser o inventor da lira nesse hino, sabe que ela também pertence a Apolo, de modo que somente depende dele aprender ao que anseia. Mostra-se por meio do diálogo do hino homérico entre o deus de Delfos e Hermes que a resposta do filho de Maia apenas reafirma um Apolo presciente - que aprendeu de Zeus as honras dos oráculos e profecias. Dessa forma, "todas as ações, decisões, falhas de êxitos do indivíduo têm fonte não na individualidade dele mas nessa natureza supra individual que caracteriza o génos" (TORRANO, 2001, p. 75). Quando Hermes afirma a Apolo: "Só de ti depende aprender o que anseias!", como visto acima, apenas repete algo já conhecido, pois, após suas perguntas, Apolo mesmo as responde: "Exatamente os três aliam-se a um só tempo:/ a alegria, o amor e o sono suave - é só escolher" (HOMERO, 2010b, p. 440). Relembrando as perguntas de Apolo junto a suas próprias respostas: "Que arte é essa?": a alegria; "que musa é essa de incontroláveis cuidados?": o amor; "Qual é o caminho?": o sono suave (essas resposta e perguntas podem ser combinadas entre si de outras maneiras sem que o sentido se perca).

\section{AS TRADICIONAIS INTEPRETAÇÕES SOBRE O APOLO DE NIETZSCHE}

São as características do Hino Homérico a Hermes que Nietzsche destaca em relação ao deus Apolo e a determinadas representações que o corpo produz. "Em que sentido foi possível fazer de Apolo o deus da arte? Só enquanto é o deus 
das representações oníricas" (NIETZSCHE, 2007a, p. 244). Para Nietzsche, um impulso fisiológico teria esculpido os deuses olímpicos e feito com que os gregos acreditassem neles como reais. "O mesmo impulso, que se materializou em Apolo, engendrou todo o mundo olímpico e, nesse sentido, Apolo deve ser reputado por nós como o pai desse mundo" (NIETZCHE, 2007b, p. 32). Dessa forma, em O nascimento da tragédia, Nietzsche enfatiza as características do olímpico Apolo homérico, ameniza outros traços apolíneos (como a crueldade e a vingança) e ignora propositalmente uma imensa riqueza cultural relacionada a outros cultos e deuses da Grécia Antiga .

Os intérpretes seguem geralmente o mesmo caminho quando objetivam explicar e afirmar as hipóteses nietzschianas ou percorrem o percurso inverso quando querem criticá-las. No primeiro caso, as intepretações sobre $\mathrm{O}$ nascimento da tragédia destacam alguns e amenizam outros traços do deus de Delfos e ignoram outros contextos apolíneos presentes nesse livro. No segundo caso, destacam cultos e personalidades de Apolo contrárias às características apolíneas vigentes em $\mathrm{O}$ nascimento da tragédia. Em ambos, no entanto, desprezam a história e as transformações de Apolo apresentadas no primeiro livro desse filósofo. Ou seja, os intérpretes assumem um Apolo homérico especificamente destacado por Nietzsche como se ele fosse o único presente em O nascimento da tragédia. Se Apolo é tal, ele o é dentro de um contexto muito bem delimitado, independente se a atenção que Nietzsche dá a um ou outro desses contextos é maior ou menor. Por isso, claro!, Apolo é o deus da medida, da luz, da beleza, da ética para Nietzsche, mas, basicamente, o é entre a época homérica e a época trágica. 
Segundo Andler, influenciado por Anselm Feuerbach e Otfried Müller, Nietzsche demonstra que Apolo é, para os gregos, "o deus das belas aparências e o deus dos sonhos e das profecias" (1921b, p. 33). Por conseguinte, os escultores, pintores e poetas épicos antigos viveram essencialmente sob a influência apolínea traduzida em suas artes. Para que essa beleza fosse vista, suas formas deveriam possuir contornos precisos e, por isso, "Apolo, deus da luz, passa para o deus da individuação" (ANDLER, 1921b, p. 34). Andler percebe as transformações apolíneas ao longo d' O nascimento da tragédia. Ele nos explica a passagem de "deus da luz" para "deus da individuação" como uma necessidade lógica interna ao apolíneo: por reconhecermos os belos contornos, reconhecemos também os limites tanto de uma poesia quanto de uma pessoa - o que formularia tanto a individualidade quanto a ética apolínea nietzschiana .

No entanto, historicamente, quando e como essa passagem acontece de modo efetivo na vida grega? Andler não formula essa questão. Além da especificidade dela, propriamente $\mathrm{O}$ nascimento da tragédia não pode respondê-la diretamente. Isso não quer dizer que Nietzsche não a tinha em vista. "O Apolo dórico", por exemplo, "que é o verdadeiro, foi o preceptor de uma arte rude, de uma educação rígida, de uma política cruel e sensata" (ANDLER, 1921b, p. 43). Claramente esse trecho difere da bela aparência, da poesia épica, da medida e do deus da "individuação". Apesar disso e da tirania que o instinto apolíneo tende (ANDLER, 1921a, p. 392), Andler não hesita em dizer que "Apolo é o deus da medida e do conhecimento que nos faz perceber nosso limite" (1921b, p. 57).

Seguindo essa linha de pensamento, temos que desprezar uma série de cultos da Grécia Antiga e somente poderí- 
amos considerar o pensamento nietzschiano como uma grande inocência e idealização sobre o apolíneo. "Diante desses nexos, a significação que Nietzsche atribui a Apolo mostra-se insuficiente" (COLLI, 1992, p. 12). Giorgio Colli foi um grande leitor de Nietzsche; filólogo, nos apresentou no primeiro volume de La sapienza greca inúmeros trechos e fragmentos de autores da antiguidade relacionados a Apolo e a outros deuses e, junto com Mazzino Montinari, organizou criticamente as obras completas de Nietzsche. Para Colli, a aparência apolínea nietzschiana é, "ao mesmo tempo, bela e ilusória, e por isso a obra de Apolo é essencialmente o mundo da arte entendida como libertação, mesmo que ilusória, do terrível conhecimento dionisíaco, da intuição da dor do mundo" (COLLI, 1992, p. 13). Contra essa perspectiva, "pode-se, antes de mais nada, objetar que a contraposição entre Apolo e Dioniso, como entre arte e conhecimento, não corresponde a muitos e importantes testemunhos históricos referentes a esses dois deuses" (COLLI, 1992, p. 13). A intenção de Colli é demonstrar que a riqueza do mundo grego torna pobre a concepção nietzschiana sobre Apolo, e vice-versa .

"Outro elemento frágil na interpretação de Nietzsche está em apresentar os impulsos apolíneos e dionisíacos como antitéticos" (COLLI, 1992, p. 15). A relação entre a sabedoria grega e Apolo oferece, em uma das versões desse deus, uma íntima proximidade com as características do Dioniso composto por Nietzsche. Segundo Colli, "um fragmento nos informa que Pitágoras - justamente um sábio foi denominado pelos crotoniatas como Apolo hiperbóreo" (1992, p. 15). Assim, a intepretação pretende demonstrar que também existe um caráter extático apolíneo, "manifestando-se no arrebatamento da pítia, nas palavras delirantes 
do oráculo délfico" (COLLI, 1992, p. 15). Para isso, Colli indica o diálogo Fédro, onde "coloca-se em evidência, portanto, desde o início, a ligação entre 'mania' e Apolo" (COLLI, 1992, p. 16). Nesse diálogo, Sócrates, indicado pela própria Pítia como o mais sábio (PLATÃO, 1972, p. 14), diz que "muitos dos nossos bens nascem da loucura inspirada pelos deuses. Efetivamente é em estado de delírio que as profetisas de Delfos e as sacerdotisas de Dódona, prestam grandes serviços à Grécia” (PLATÃO, 2000, p. 53) .

Para entender que a filosofia nietzschiana distancia a relação de Apolo com Dioniso como Colli faz, deve-se crer que, para Nietzsche, Apolo é somente o deus da medida e da harmonia e que ele "considera a loucura pertinente apenas a Dionísio" (COLLI, 1992, p. 16). Mas, se estimarmos suas obras filológicas, fica difícil imaginar que Nietzsche não conhecia a relação de Pitágoras com Apolo hiperbóreo - pois justamente Diôgenes Laêrtios ${ }^{3}$ comenta essa lenda (2008, p. 231). Além disso, no Fragmento-Póstumo 7[122] (NIETZSCHE, 1988b, p. 170-176), o filósofo relaciona Pítia e Sibila, personagens possuídas por Apolo, com a Diotima socrática. $\mathrm{Na}$ verdade, ao focarmos $\mathrm{O}$ nascimento da tragédia, ressalta-se inclusive a inspiração divina de Sócrates que vinha "de um deus ou de um gênio" (PLATÃO, 1972, p. 23) sem dizer seu nome ou mencionar Apolo. "Em situações especiais, quando sua descomunal inteligência começava a vacilar, conseguia ele um firme apoio, graças a uma voz divina que se manifestava em tais momentos. Essa voz, quando vem, sempre dissuade" (NIETZSCHE, 2007b, p.

\footnotetext{
${ }^{3}$ Antes de se tornar professor, Nietzsche desenvolveu trabalhos tão talentosos sobre Diôgenes Laêrtios e Teógnis que se destacou no meio filológico. Por culpa de tais trabalhos, o filósofo recebeu da Universidade de Leipzig o seu doutorado sem precisar apresentar nenhuma tese e assumiu a cátedra da Universidade de Basileia em 1869.
} 


\section{3). A interpretação de Nietzsche não considera o "daimon"} de Sócrates ${ }^{4}$ relacionado a Apolo; o que não significa também que ele não considere a força socrática como divina ou, quiçá, possessiva.

Dessa forma, pode-se identificar no pensamento do jovem Nietzsche a possessão divina não apenas de modo dionisíaco, mas também de modo apolíneo e até socrático. Diferentemente à defesa de Colli, o filósofo não reduz possessão a Dioniso, como se desconsiderasse os dons extáticos apolíneos relacionados também com as Musas. Inclusive, o Fragmento-Póstumo 1[64] de 1869 (NIETZSCHE, 1988b, p. 29-30) cita a passagem 245 enquanto Colli $(2005$, p. 81) cita a passagem 244 de Fédro de Platão. No entanto, apesar de longa, essa exposição não pretendeu repetir a intenção de Bittencourt (2012), mas demonstrar que O nascimento da filosofia de Colli está na linha de tantos outros intérpretes

\footnotetext{
${ }^{4}$ Nietzsche induz-nos a um paradoxo (não à toa, ele usa as aspas ao se referir ao „Dämonion des Sokrates" (1988b, p. 90)). Segundo MALHADA et al., daimonio significa: "inspirado por uma divindade" (2007, p. 194), o que resulta em um estado não consciente, instintivo. No entanto, Sócrates é o símbolo pleno da consciência e da crítica, mas "enquanto, em todas as pessoas produtivas, o instinto é justamente a força afirmativa-criativa, e a consciência se conduz de maneira crítica e dissuasora, em Sócrates é o instinto que se converte em crítico, a consciência em criador" (NIETZSCHE, 2007c, p. 83). Dessa forma, de acordo com o pensamento de Nietzsche, podemos afirmar que Sócrates também é possuído, como acontece tanto com a Pítia como com as bacantes, no entanto, a força que o possuí o transforma em uma "uma verdadeira monstruosidade per defectum!" (NIETZSCHE, 2007c, p. 83), porque justamente o seu lado instintivo, a sua falta de consciência, é também o estado mais avançado de lucidez e lógica: diferente de Apolo e de Dioniso, pois, com ambos os deuses, suas possessões retiram a consciência e o caráter lógico do possuído. Por isso, Nietzsche afirma paradoxalmente que o maior exemplo de homem teórico, crítico, lógico da Grécia Antiga é tomado também por uma força demoníaca [dämonische Kraft] (1988b, p. 90). Poderíamos, inclusive, adensar estas voltas lógicas: se o verdadeiro Sócrates não seria propriamente esse daimon, mas, além do cansaço e da tontura, teríamos também que admitir que, posteriormente, ou o Sócrates-daimon é aniquilado ou, ainda mais paradoxal, sua força divina é possuída e faz música (o que faz certo sentido perante Dioniso) - em ambos os casos, aumentaríamos a corrida e a vertigem. Cabe ressaltar, porém, dois pontos. Primeiro, Nietzsche formula aqui um novo cenário sobre a interpretação do daimon grego socrático. Segundo, assim nem interpretação de Colli de que "Nietzsche considera a loucura pertinente apenas a Dioniso" (1992, p. 16) - e aqui estamos relacionando-a ao sentido de posse divina - nem a interpretação de Dodds de que Nietzsche havia estabelecido a impressionante antitese "entre a religião 'racional' de Apolo e a religião 'irracional' de Dioniso” (2002, p. 75) faz sentido.
} 
que consideram somente o Apolo belo e comedido de $\mathrm{Ni}$ etzsche. Diferente de Andler que, ao menos, faz uma ressalva, Colli eleva um dos Apolos de Nietzsche a uma máxima e única evidência como se outros sentidos do apolíneo não existissem.

Silk e Stern intensificaram essa perspectiva. "De todas as distorções encarnadas na versão de Nietzsche da religião grega, a mais importante e a mais complicada é sua representação de Dioniso e Apolo" (SILK e STERN, 1983, p. 166). Eles fazem uma leitura sobre a Grécia Antiga ainda mais rica do que a de Colli para demonstrar que a abundância das deidades gregas estava muito além dos deuses Olímpicos e do Dioniso de O nascimento da tragédia. Apolo foi deus da medicina, da música (especialmente, a lira), tinha associação com rebanhos. Delfos "foi o sítio de seu grande oráculo, onde a sacerdotisa, em estado de êxtase religioso, mediou suas profecias" (SILK e STERN, 1983, 169); purificava, também foi um deus da ordem e da lei, deus do sol, deus da luz, do sonho e da ilusão; Apolo arqueiro, também remetente de praga. A lista de predicados e cultos é tão grande que, em algum momento, é necessário perguntar "qual Dioniso e qual Apolo?", indagação que, para Silk e Stern (1983, p. 180), não está entre as preocupações de Nietzsche.

O problema para Silk e Stern está no aumento de significado que Nietzsche dá a Apolo e a Dioniso transformando-os em verdades quase históricas, ou seja, na reinterpretação nietzschiana que extrapola as provas e as teorias existentes sobre a Grécia Antiga. Em A visão dionisíaca do mundo (NIETZSCHE, 2007a, p. 245), Apolo

é "o Resplandecente" de modo total: em sua raiz mais funda é o deus do sol e da luz, que se revela no resplendor. A "belezza" é seu 
elemento: eterna juventude lhe acompanha. Porém também a bela aparência do mundo onírico é seu reino: a verdade superior, a perfeição própria desses estados, que contrasta com a só fragmentariamente inteligível realidade diurna, eleva-o à categoria de deus vaticinador, porém também certamente de deus artístico.

Entre os filólogos, não há discordância sobre determinadas características de Apolo como o brilho e a bela aparência, desde que elas estejam bem contextualizadas e evidenciadas temporalmente e espacialmente. Etimologicamente, não há concordância sobre a sua acepção ${ }^{5}$. No entanto, em $\mathrm{O}$ nascimento da tragédia, Nietzsche lhe dá o significado "segundo a raiz do nome 'resplendente"' (2007b, p. 26), extrapolando filologicamente a onomástica do deus de Delfos, pois o filósofo não está considerando o vocábulo grego e, sim, o alemão. Segundo Pascual (2007, p. 278, nota 32),

Ao dizer que Apolo significa etimologicamente der Erscheinende, Nietzsche tinha - em alemão - um fácil pretexto para fazê-lo divindade do Schein [brilho, aparência] e pô-lo em relação com Erscheinung [aparência, aparição, fenômeno]. Se se tem em conta que o vocabulário empregado por Nietzsche aqui é o schopenhaueriano e kantiano, baseado, portanto, na contraposição entre "a coisa em si" [das Ding an sich] e "a aparência” [die Erscheinung], compreender-se-á melhor a relação estabelecida por Nietzsche entre Apolo e a "aparência".

Concepções iguais a essa embasam corretamente a crítica filológica de Silk e Stern e também de WilamowitzMöllendorff, pois "certamente é uma enorme ousadia fazer de Apolo, que 'pela raiz de seu nome é o brilhante', graças a um jogo de palavras, 'o deus da aparência'” (WILAMOWITZ, 2005, p. 61). Para complicar ainda mais, a datação em $\mathrm{O}$ nascimento da tragédia é imprecisa. Os sécu-

\footnotetext{
${ }^{5} \mathrm{Na}$ verdade, Nietzsche sabia disso, como diz em seu curso Enciclopédia de Filologia Clássica de 1871: "Apollo Lichtgottheit, Name selbst unerklärt" [Apolo, deus da luz, o próprio nome desconhecido]. (NIETZSCHE, 1993, p. 411).
} 
los se evidenciam somente com a erudição do leitor e com os nomes de artistas, filósofos e políticos deixados por Nietzsche. Podemos traçar, por exemplo, uma linha histórica da poesia por meio de Homero, Terpandro, Arquíloco, Ésquilo, Sófocles, Eurípides e Aristófanes conforme citações cronologicamente desordenadas; ou, uma trajetória da filosofia a partir de Heráclito de Éfeso, Anaxágoras de Clazômenas, Sócrates, Platão, Aristóteles, etc. No entanto, o cenário se complica em relação a Apolo e a suas épocas, pois, não estando evidenciadas claramente, dão inicialmente a impressão de que Nietzsche generaliza onde não pode ser generalizado. Ou seja, quando Nietzsche relaciona Apolo à bela aparência e à ética, tem-se a impressão de que ele está falando unicamente de um Apolo, um mito, uma crença, um único grupo de características quando, na verdade, a Grécia Antiga possuía vários mitos e crenças.

Silk e Stern partem da mesma problemática que Wilamowitz para criticar $\mathrm{O}$ nascimento da tragédia, isto é, as extrapolações interpretativas de Nietzsche isentas de demonstrações e provas que objetivam fazer-se historicamente reais. Contudo, não podem se aliar plenamente a esse filólogo. Enquanto Silk e Stern contrapõe a riqueza cultural grega ao ingênuo e parco Apolo "nietzschiano" demonstrando que, "no período clássico, cada divindade não tinha apenas uma função ou funções, mas também características identificáveis" (1983, p. 166), a primeira crítica de Wilamowitz à Nietzsche é exatamente o oposto. Para Wilamowitz, Nietzsche abrange um período progressivamente imenso, ora com seu "proto-Apolo" da época préhomérica sem sequer "discutir se teria realmente havido um tempo no qual um heleno, ignorando Zeus, Atena e Apolo, teria oferecido sacrifícios a Urano ou Cronos, ou mesmo a 
Ericapero e a Fanes" (WILAMOWITZ, 2005, p. 63), ora com o seu "Apolo da época homérica" que, para Wilamowitz, não condizia com a realidade da cultura grega porque "o Apolo da época homérica mal carregava o germe do poder político-religioso que passou a possuir a partir do século VIII" (WILAMOWITZ, 2005, p. 61).

Como se vê, o objetivo de cada crítica difere apesar dos pontos em comum. Silk e Stern pretendem demonstrar a desconsideração de Nietzsche pela multiplicidade grega; Wilamowitz pretende, ao contrário, demonstrar a excessiva consideração nietzschiana por uma Antiguidade que não possuía testemunhos filológicos. Os três autores almejam evidenciar a Grécia inventada por Nietzsche, cuja razão lhes está correta. Grande parte das teorias sobre a antiguidade grega de $\mathrm{O}$ nascimento da tragédia, sobretudo o seu entendimento de uma cultura "pré-homérica", não tinha provas reais. Por isso, segundo esse par de autores, Wilamowitz "negou vigorosamente a evidência de tal cultura préhomérica, e não existe dúvida que a teoria de Nietzsche foi especulação essencialmente" (SILK e STERN, 1983, p. 163). No entanto, mesmo sendo especulação, a intenção d' O nascimento da tragédia era exatamente contrária à crítica de Silk e Stern. Ao dar importância a um período "préhomérico" e "homérico", Nietzsche se põe contra noções e atitudes da filologia moderna, como o "milagre grego", a fim de evidenciar culturas pouco exploradas em sua época e, como o próprio Rohde notou, "para mostrar que o brilho alegre do mundo homérico não caiu do céu da noite para o dia" [itálico meu] (2005a, p. 100).

As amplitudes das críticas são inversamente proporcionais. Por um lado, Wilamowitz ressalta a realidade da Grécia Antiga conhecida por sua época para atacar por inteiro a 
sabedoria d' O nascimento da tragédia "conseguida via intuição" (2005, p. 56). Por outro, tanto Silk e Stern quanto Colli ressaltam uma parte da lógica apolínea de Nietzsche para compará-la com a Grécia Antiga. Enquanto Wilamowitz demonstra que o leque hipotético aberto por $\mathrm{Ni}$ etzsche é irresponsavelmente maior do que as provas e conhecimentos que existiam, Colli, Silk e Stern demonstram que as hipóteses nietzschianas não abrangem o conhecimento existente sobre a Grécia Antiga ${ }^{6}$. Dessa forma, a interpretação de Colli, Silk e Stern assemelham-se a uma metástase, como se legassem a Nietzsche uma posição inversa e mais condizente a Wilamowitz do que ao próprio $\mathrm{Ni}$ etzsche.

O problema de $\mathrm{O}$ nascimento da tragédia não é ignorar ou desconhecer a multiplicidade apolínea da Grécia Antiga a partir da consideração de Apolo somente como um deus da medida, da luz, da beleza, etc. Ao contrário, os problemas filológicos de $\mathrm{O}$ nascimento da tragédia se concentram basicamente em: primeiro, abranger um imenso período e inúmeros cultos habilmente manipulados por Nietzsche sem qualquer referência, sob o mesmo nome "Apolo", como se eles formassem etapas em um progresso linear de transformações ${ }^{7}$. Segundo, exaltar características específicas de Apolo em uma dessas etapas, não por ser o único Apolo existente em seu pensamento, mas, porque ele condiz com os objetivos filosóficos e políticos de $\mathrm{O}$ nascimento da tragédia em relação tanto à época trágica quanto a época do pró-

\footnotetext{
${ }^{6}$ É claro que nem aqui nem em outras interpretações podemos correr o risco de responsabilizar Nietzsche e Wilamowitz por conhecimentos posteriores aos de sua época.

${ }^{7}$ Assim, não há simplesmente um sincretismo entre Apolo e Dioniso (SILK e STERN, 1983, p. 178), mas, sim, inúmeros sincretismos em O nascimento da tragédia: entre vários elementos e cultos apolíneos, entre vários elementos e cultos dionisíacos, entre os dois deuses, entre Apolo e as divindades olímpicas, entre Dioniso e os seres ctônicos e titânicos, etc.
} 
prio Nietzsche e de Wagner.

\section{APOLO DESMESURADO CONTRA SUA NECESSÁRIA REDENÇÃO}

"E assim corre, ao lado da necessidade estética da beleza, a exigência do 'Conhece-te a ti mesmo' e 'Nada em demasia'” (NIETZSCHE, 2007b, p. 37). Se existe toda uma relação entre Apolo e a Natureza, os Titãs e o titânico, é porque o homem como força também é e se relaciona com o natural: são os impulsos apolíneos diante de outros homens e da Natureza em suas forças constitutivas. Quando Apolo tomou distância do mundo titânico, viu-o com repulsa, mas contemplou-o. Qualificado como observador, o apolíneo representa o mundo em suas formas tomando consciência dele através da beleza e segurança. "Aqui temos, diante de nossos olhares, no mais elevado simbolismo da arte, aquele mundo apolíneo da beleza e seu substrato, a terrível sabedoria do Sileno, e percebemos, pela intuição [Intuition], sua recíproca necessidade" (NIETZSCHE, 2007b, p. 37). Nestas representações, o preceito délfico encontra o seu auge e o homem aprende os seus próprios limites perante forças maiores: aprende a ética em relação à Natureza, aos próprios homens e a si, "pois Apolo quer conduzir os seres singulares à tranquilidade precisamente traçando linhas fronteiriças entre eles e lembrando sempre de novo, com suas exigências de autoconhecimento e comedimento, que tais linhas são as leis sagradas do mundo" (NIETZSCHE, 2007b, p. 65).

Conhecendo as forças da Natureza, o desmedido é "mensurado": o apolíneo tenta controlar o que ameaça a sua existência. Por isso, as representações apolíneas têm em 
si e para si aqueles dois ensinamentos. Apolo é o "conhecete a ti mesmo" e o "nada em demasia", mas paradoxalmente, também precisa estar consciente deles, consciente de si, como se a todo o momento precisasse se lembrar de quem se é para continuar a ser o que se é. Neste sentido, ensinanos muito a passagem da Ilíada em que sabiamente Apolo renega a Posídon lutar contra os deuses pelos homens, aqueles que passam com o ocaso e caem e secam como as folhas. Ora, conhecendo a si em suas limitações não é possível prever as consequências negativas causadas por atos desmedidos? Em suas representações e limitações, Apolo se torna, portanto, vidente: aquele que vê diante de si o presente e o futuro. Por conseguinte, o olhar de Apolo "deve ser 'solar', em conformidade com sua origem; mesmo quando mira colérico e mal-humorado, paira sobre ele a consagração da bela aparência" (NIETZSCHE, 2007b, p. 26).

Apolo é belo porque mantém certa distância do mundo titânico sem desconhecê-lo, mantém a distância porque o conhece e é belo e, ainda, o conhece porque mantém a distância e é belo - não é meramente um jogo de palavras, mas três distintas e concomitantes sequências que motivam a medida apolínea! Como o pensamento de Heráclito influenciando Nietzsche, a unidade é a multiplicidade. Portanto, em uma existência de horror, contradição e ameaça à vida, Apolo envolve o homem através de suas características constitutivas de distância, beleza e conhecimento, enfim, de medida como proteção e aparência que, conhecendo a si mesma, não perde de vista o mundo do qual se distanciou. Assim, Apolo

mais uma vez se nos apresenta como o endeusamento do principium individuationis, no qual se realiza, e somente nele, o alvo eternamente 
visado pelo Uno-Primordial, sua libertação através da aparência: ele nos mostra, com gestos sublimes, quão necessário é o inteiro mundo do tormento, a fim de que, por seu intermédio, seja o individual forçado a engendrar a visão redentora e então, submerso em sua contemplação, remanesça tranquilamente sentado em sua canoa balouçante, em meio ao mar. (NIETZSCHE, 2007b, p. 37)

Mas o que é esta "redenção através da aparência", esta "constante redenção" que Nietzsche comenta? por que é necessário uma "libertação através da aparência", uma "visão redentora" (NIETZSCHE, 2007b, p. 36-37)?

Porque, imerso no mundo, em uma "realidade" constantemente fugaz em que suas formas se desfazem e se refazem, "a 'aparência' [Schein] é aqui reflexo [Widerschein] do eterno contraditório, pai de todas as coisas" (NIETZSCHE, 2007b, p. 37); por isso, as representações apolíneas também precisam estar em movimento, para estar de acordo com o reflexo do "eterno contraditório". Como dito acima: Apolo precisa de seus contrários! Foi assim que o mundo homérico se fez por meio das belas imagens com a crueldade subentendida nelas: ou seja, por mais que Apolo adornasse a realidade através de seus atributos, sempre a "sabedoria de Sileno" deveria existir - por uma questão estética, existencial e lógica! Mas, para Nietzsche, com a "derrota" do mundo titânico, as representações apolíneas foram se intensificando ${ }^{8}$.

A existência de tais deuses sob o radioso clarão do Sol é sentida como algo em si digno de ser desejado e a verdadeira dor dos homens homéricos está em separar-se dessa existência, sobretudo em rápida separação, de modo que agora, invertendo-se a sabedoria de Sileno,

\footnotetext{
${ }^{8}$ Uma interpretação que faço disso é a distância temporal que vai aumentando em relação ao mundo "pré-homérico", "titânico" de Nietzsche: como se os próprios corpos dos gregos fossem se "esquecendo" de seu passado e, por isso, perdendo o seu verdadeiro contato (sua sensação [Empfindung]) com o mundo titânico e o substrato tão necessário de dor e prazer.
} 
poder-se-ia dizer: "A pior de todas as coisas é para eles morrer logo; a segunda pior é simplesmente morrer um dia”. (NIETZSCHE, 2007b, p. 34)

O extremo gosto e cuidado pela vida não faz com que, paradoxalmente, ela não seja vivida? - não cria o medo de perdê-la? A cultura homérica teria chegado a um ponto cujo trajeto seria inverso. Isto é: com os adornos e as seguranças das representações apolíneas, a própria vida teria sido vítima de uma limitação que atuaria desmesuradamente como o contrário de sua essência, a saber, "como imperativo ou como censura” (NIETZSCHE, 2007b, p. 35). A desmesura que Apolo evitava não era apenas causada por impulsos irrefletidos e inconsequentes.

Devido ao seu amor titânico pelos seres humanos, Prometeu teve que ser dilacerado pelos abutres; por causa de sua desmesurada sabedoria, que solucionou o enigma da Esfinge, Édipo teve de precipitar-se em um enredante turbilhão de crimes: era assim que o deus délfico interpretava o passado grego. [itálico meu] (NIETZSCHE, 2007b, p. 38)

Ora, Nietzsche evidencia que a desmesura em geral não condiz com o "deus délfico": mesmo a sabedoria demasiada não protegeu Prometeu nem Édipo daqueles sofrimentos e tormentos característicos da existência da era titânica. "E agora imaginemos como nesse mundo construído sobre a aparência e o comedimento, e artificialmente representado, irrompeu o tom extático do festejo dionisíaco" (NIETZSCHE, 2007b, p. 38). Cabe ressaltar, aqui, que, na Grécia a partir do século VIII a. C., venerações ao deus Dioniso se intensificaram. Para Nietzsche, no êxtase e no descontrole dos cultuadores dionisíacos, o grego apolíneo teria identificado em tais rituais resquícios daquele tempo titânico rival do deus de delfos. Iniciada a "guerra" entre Apolo e 
Dioniso: em um primeiro momento, Apolo resistiu, ou melhor, as representações apolíneas conscientes de seus limites, de suas fronteiras individuais, inibiram aquele comportamento dionisíaco descontrolado e extasiado tão estranho ao seu.

"Mas, é igualmente certo que lá onde o primeiro assalto foi suportado, o prestígio e a majestade do deus délfico se externaram de maneira mais rígida e ameaçadora do que nunca" (NIETZSCHE, 2007b, p. 38-39). Para suportar as primeiras ondas dionisíacas, as representações apolíneas teriam que ter diminuído ainda mais suas fronteiras e ainda mais atuado como imperativas e censuradoras para que $\mathrm{o}$ grego soubesse o que lhe era permitido, vergonhoso, perigoso, etc. Diz Nietzsche somente assim conseguir explicar o Estado dórico e a arte dórica, como um acampamento apolíneo de guerra: "só em uma incessante resistência contra o caráter titânico-barbaresco do dionisíaco podia perdurar uma educação tão belicosa e áspera, um Estado de natureza tão cruel e brutal" (NIETZSCHE, 2007b, p. 39). Interessante notar a inversão que Nietzsche faz: o "Estado de natureza tão cruel e brutal", a "educação tão belicosa e áspera" pertencem às artes e políticas estatais dóricas - podendo ser identificadas entre os séculos VIII e VII a. C., ou seja, os últimos suspiros do período apolíneo antes da época trágica segundo Nietzsche .

Para proteger-se daquelas influências estranhas, as características apolíneas de beleza, autoconhecimento e tranquilidade se tornaram mais rígidas e fixas. A externação do prestígio e da majestade do deus délfico de maneira rígida e ameaçadora não é a desmesura de Apolo? não é a proteção para que se viva através da impossibilidade de se viver plenamente dentro de limites já postos por experiências obti- 
das com o confronto entre o apolíneo e o titânico? Há, assim, algumas perguntas em relação a Apolo. Apolo e o apolíneo já não teriam perdido a sua própria medida antes que o dionisíaco começasse a insurgir? pois, se as representações apolíneas precisam refletir a própria existência, mesmo que a medindo, então a distância perante a vida não era demasiada grande a ponto de ignorar e confrontar qualidades dionisíacas que são tão naturais quanto as apolíneas? ${ }^{9} \mathrm{E}$ mais ainda -: com as chegadas dionisíacas, as representações apolíneas (externadas pela arte, política, etc.) não foram além de suas fronteiras individuais impondo inclusive quais fronteiras seguir? - ou seja, um "conhece-te a ti mesmo" cujo conhecimento pouco se sabe além da representação imagética. Essas duas perguntas ainda nos levam a outra, derradeira: o descontrole de Apolo perante "o-que-seviver" e "o-que-não-se-viver" significa que existem tipos de desmesuras ou que Apolo já estaria sob efeito de Dioniso?

Independente das perguntas acima: Apolo não se "redimiu". A palavra "redenção" (Erlösung) é de difícil análise na filosofia de Nietzsche. Em sua obra Nietzsche contra Wagner, o filósofo a utiliza, sobretudo, ironicamente segundo a tradição cristã para criticar aqueles que a usam ou que agem de acordo com o seu significado, sobretudo, Wagner. Mas, em $\mathrm{O}$ nascimento da tragédia, o significado da palavra "redenção" e de suas derivações aparece de modo restrito e consciente, apesar da conflituosa relação desta época de Nietzsche para com a religião. Uma prova clara para isso está em sua Tentativa de Autocrítica, escrita anos depois, onde se

\footnotetext{
${ }^{9}$ Como se as representações apolíneas tivessem tomado uma distância tão grande das sensações de prazer e desprazer que os gregos passariam a viver em sonhos. Para deixar mais factível: como se as imposições estatais, políticas, em suma, civis impedissem as experiências gregas plenas de prazer e de dor que, por conseguinte, são as próprias criadoras das representações apolíneas.
} 
acentua um tom severo e crítico para consigo mesmo, porém, nela, Nietzsche diz:

O mundo, em cada instante a alcançada redenção de deus, o mundo como a eternamente cambiante, eternamente nova visão do ser mais sofredor, mais antitético, mais contraditório, que só na aparência [Schein] sabe redimir-se: toda essa metafísica do artista pode-se denominar arbitrária, ociosa, fantástica - o essencial nisso é que ela já denuncia um espírito que um dia, qualquer que seja o perigo, se porá contra a interpretação e a significação morais da existência. (NIETZSCHE, 2007c, p. 16)

Ou seja, mesmo depois de Nietzsche formular a sua filosofia contra o cristianismo, Kant, Schopenhauer e Wagner, ainda assim, ele utiliza as palavras "redenção" e "redimir-se" associando-as à efemeridade ("em cada instante"), à mutabilidade ("eternamente cambiante"), à aparência e à metafísica do artista em favor da afirmação da vida. Apolo precisava se redimir, se salvar de si mesmo! - de suas aparências quando elas se solidificavam perante o movimento da vida. Como Nietzsche argumenta, o fundamento apolíneo reflete apenas a existência em sua transformação, contradição e dor através de belas e calmas imagens. Quando as representações apolíneas se congelam em um único modelo, em uma única aparência, em "métodos" de se viver, não admitindo a bramante vida dionisíaca, elas cortam sua ligação com a existência e suas sensações despertas e passam a existir de modo patológico. Aquela aparência enrijecida se tornava o "modo" de se viver, ou seja, a aparência enganava como "realidade grosseira" perante as ondas dionisíacas.

\section{CONCLUSÃO}

Nietzsche não queria apenas enfatizar as qualidades 
apolíneas para combiná-las com seu dionisíaco e harmonizar suas hipóteses sobre a Grécia Antiga, como também queria estendê-las ao presente e futuro alemães. Para isso, o filósofo tinha que delimitar sua concepção sobre Apolo (que em seus textos filológicos se mostra bem diferente ${ }^{10}$ ) e amenizar uma série de pontos sobre a cultura grega da antiguidade. Objetivei demonstrar, no entanto, que grande parte das interpretações sobre o Apolo de Nietzsche desconsidera a multiplicidade d' $\mathrm{O}$ nascimento da tragédia. Os intérpretes ${ }^{11}$ assumem geralmente uma postura semelhante à de Nietzsche: enfatizam um determinado Apolo, relacionando-o com as características de beleza, ética, aparência, etc. - seja para afirmar o pensamento nietzschiano seja para criticá-lo, mas eles desconsideram inúmeras outras circunstâncias que Nietzsche não desconsiderou. Quando comentam $\mathrm{O}$ nascimento da tragédia nomeiam os atributos de Apolo e do impulso apolíneo como se Nietzsche os tivesse considerado imutáveis desde o período pré-homérico até

\footnotetext{
${ }^{10}$ Apesar do foco deste artigo ser O nascimento da tragédia, convém aqui algumas referências sobre os textos de filologia de Nietzsche e outros do mesmo período de seu primeiro livro. Em Os cinco prefácio para cinco livros não escritos (2007d), o nome de Apolo aparece em dois prefácios. No primeiro ("O estado grego"), Nietzsche diz: "é Apolo, o deus que consagra e purifica o estado" (p. 51 52), ou seja, no limite, podemos estabelecer uma relação entre o deus e a política. No segundo ("A disputa de Homero"), Nietzsche cita dois casos interessantes de Apolo: a) a luta de "Marsias com Apolo" e b) "o destino comovente de Níobe" (p. 70) - os dois exemplos revelam um Apolo sanguinário para além de toda a beleza. Além disso, no parágrafo 19, "Sobre a religião e a mitologia dos antigos", em seu curso já citado Enciclopédia de Filosofia Clássica tem parte dedicada ao deus: Nietzsche fala de seus cultos e lugares onde eles aconteciam, fala de suas características relacionadas ao rebanho, à profecia, à música, ao clima, à purificação, etc. (1993, p. 411 - 412). Entre outros exemplos, Nietzsche expõe concepções sobre Apolo destoantes de O nascimento da tragédia ou que, ao menos, não enfatizam tanto ou somente os aspectos relacionais à beleza e à medida apolíneas.

${ }^{11}$ Devemos levar em conta inúmeras posições dentro da crítica especializada relacionadas a Nietzsche. Aqui, evidenciamos alguns autores importantes para o estudo do pensamento nietzschiano devido à riqueza de seus argumentos. No entanto, também os pesquisadores evidenciaram outras interpretações sobre o Apolo nietzschiano como, por exemplo, o caso de Roberto Machado em seu livro O Nascimento do Trágico demonstrando que em vez de desconsiderar o "lado sombrio e vingativo" presente na Ilíada, o Apolo de Nietzsche o aceita e o conversa a seu modo.
} 
a modernidade: ou seja, como se, do primeiro ao último capítulo desse livro, Apolo fosse sempre o mesmo, com as mesmas características, proporções e intensidades, e como se a bela aparência e a medida apolíneas fossem tão sólidas e seguras que não pudessem recair em um perigo patológico (NIETZSCHE, 2007b, p. 26).

Mas, em vários momentos d' O nascimento da tragédia, Apolo e Dioniso não podem ser resumidos em algumas características, por isso, é necessário contextualizá-los. Como demonstrei, no exemplo anterior, a época dórica é considerada por Nietzsche como a intensificação dos elementos éticos e imagéticos de Apolo, distanciados das esferas corporais (titânicas, dionisíacas, prazerosas e dolorosas), que, por conseguinte, o levam ao seu contrário: à desmesura - isto é, a ética e a beleza perdem os parâmetros que as constituem. Expliquei a intensificação desmesurada de Apolo por meio de um dos possíveis fundamentos existentes em $\mathrm{O}$ nascimento da tragédia relacionados às aparências criadas, às transformações e constantes mudanças da existência e aos próprios limites éticos: com as mesmas características que os intérpretes geralmente identificam um Apolo, cheguei a outro Apolo de Nietzsche pela lógica de sua filosofia .

Esta hipótese não é simples e suscita uma série de outras perguntas que poderiam ainda ser multiplicadas conforme as perspectivas filosóficas e filológicas. Enquanto defendi um Apolo desmesurado por culpa de seu distanciamento temporal e espacial de Dioniso, poderíamos ter também defendido o contrário: que justamente a aproximação dionisíaca causou a desmesura dórica apolínea. $\mathrm{Na}$ Grécia Antiga, uma das consequências da aproximação dionisíaca era, por exemplo, o delírio. Segundo Detienne, 
"quando Dioniso está ainda sob o poder de Hera, ela também perita em delírios furiosos" (1988, p. 41-42): sendo assim, por que Apolo também não poderia delirar? - tanto no seu primeiro encontro com Dioniso quanto no segundo.

Outra hipótese para explicar a desmesura de Apolo poderia ser a relação entre perseguido e perseguidor - comum entre os deuses gregos. A perseguição é recíproca em relação a Dioniso: quem persegue o deus é por ele perseguido e, inversamente, quando Dioniso persegue, o perseguido passa a segui-lo e cultuá-lo. A diferença está na perseguição benéfica e maléfica, ou seja, quem perseguia Dioniso para lhe fazer mal e quem o perseguia para compartilhar de seu êxtase: isso aconteceu com Penteu e Licurgo por um lado e, por outro, com as ninfas, os sátiros e as bacantes. Na verdade, um simples cotejo entre mitologia e $\mathrm{O}$ nascimento da tragédia poderia fundamentar essas hipóteses e gerar muitas outras. Sem falar no proto-Apolo nietzschiano, para usar a expressão de Wilamowitz, no Apolo trágico, em um possível Apolo euripidiano e socrático - mesmo que efêmero -, moderno, etc. Dessa forma, As hipóteses de Nietzsche requerem necessariamente várias outras hipóteses. Se Apolo é reduzido simplesmente a algumas características, desconsideram-se processos complexos.

Abstract: Much of the analysis of The Birth of Tragedy surround the Apollonian and Dionysian impulses that, in communion, would have originated Greek tragedy. When they refer to the Apollonian, the traditional explanation concentrates on some characteristics like beauty, appearance, ethics and dream. However, Nietzsche's first book presents a series of periods related to Apollo that deviates from its posterior interpretive tradition. One of the most obvious is the Doric period that I use here to demonstrate a unmeasured Apollo in The Birth of Tragedy against its usual characterization as a beautiful and ethical god.

Keywords: Unmeasured; Apollo; Philology; Ancient Greece. 


\section{REFERÊNCIAS}

ANDLER, C. Nietzsche, sa vie et sa penséé: La Jeunesse de Nietzsche (Vol. II). Paris: Éditions Bossard, 1921a.

- Nietzsche, sa vie et sa penséé: Le Pessimisme Esthétique de Nietzsche (Vol. III). Paris: Éditions Bossard, $1921 b$.

BRANDÃO, Junito de Souza. Mitologia grega vol. 2). Ed, Petrópolis: Vozes, 1987.

BITTENCOURT, R. N. Apolo de duas faces. Nearco (Rio de Janeiro), v. 10, p. 149-169, 2012.

CARVAlHO, Sílvia M. S. de. Apolo. In: HOMERO. Hinos Homéricos. JÚNIOR, Wilson Alvez Ribeiro (Org. e ed.). São Paulo: Editora Unesp, 2010a.

Hermes. In:

HOMERO. Hinos Homéricos. São Paulo: Editora Unesp, $2010 \mathrm{~b}$.

COLLI, G. La sapienza greca (Vol I). Milano: Adelphi Edizione, 2005 (4⿳⺈ ed.).

- O nascimento da filosofia. Trad. de Federico Carotti. Campinas: Editora UNICAMP, 1992.

DELEUZE, G. Nietzsche e a filosofia. Trad. de Ruth Joffily e Edmundo. Fernandes Dias. Rio de Janeiro: Editora Rio, 1976.

DETIENNE, Marcel. Dionísio a céu aberto. Trad. de Carmem Cavalcanti. Rio de Janeiro: Jorge Zahar, 1988. (Erudição \& Prazer). 
DODDS, E. R. Os gregos e o irracional. Trad. de Paulo Domenech Oneto. São Paulo: Escuta, 2002.

FOUCAULT, M. Nietzsche, Freud e Marx. Trad. de Jorge Lima Barreto. São Paulo: Princípio Editora, 1997.

GRAN-AYMERICH, Ève. El nacimiento de la arqueología moderna, 1798-1945. Trad. de Inés Sancho-Arroyo. Zaragoza: Prensas Universitarias de Zaragoza, 2001.

HOMERO. Ilíada (em verso). Trad. de Carlos Alberto Nunes. Rio de Janeiro, Ed. Ediouro, 2004.

2010.

. Hinos Homéricos. São Paulo: Editora Unesp,

KAUFMANN, W. Nietzsche: Philosopher, Psycologist, Anticrist. New Jersey: Princeton University Press, 1974 (4ํㅡㄹ ed.).

LAÊRTIOS, Diôgenes. Vida e doutrina dos filósofos ilustres. Trad. do grego, introdução e notas de Mário da Gama. Brasília: Editora Universidade de Brasília, 2008.

MACHADO, R. O Nascimento do Trágico: de Schiller a Nietzsche. Rio de Janeiro: Jorge Zahar, 2006.

MALHADAS, D.; DEZOTTI, M. C. C.; NEVES. Dicionário Grego-Português (vol. 1). São Paulo: Ateliê Editorial, 2007.

NIETZSCHE, F. Die Geburt der Tragödie. In: Sämtliche Werke Kritische Studienausgabe (KSA). Hrsg. G. Colli e M. Montinari. v. 1. München: Walter de Gruyter \& Co, 1988a. 
. Nachgelassene Fragmente 1869-1874. In: Sämtliche Werke Kritische Studienausgabe (KSA). Hrsg. G. Colli e M. Montinari. v. 7. München: Walter de Gruyter \& Co, 1988b.

. "Encyclopädie der klassischen Philologie". In.: NIETZSCHE, F. Kritische Gesamtausgabe: Werke (Abt. 2 Bd. 3), editada por Giorgio Colli e Mazzino Montinari. Berlin: Walter de Gruyter \& Co, 1993.

. Crepúsculo dos Ídolos, ou como se filosofa com o martelo. Trad. de Paulo César de Souza. São Paulo: Companhia das Letras, 2006a. 